\title{
HISTÓRIA DA ESCOLA NO MOVIMENTO DOS TRABALHADORES RURAIS SEM TERRA
}

\author{
Sandra Luciana Dalmagro ${ }^{1}$
}

\begin{abstract}
Resumo
O texto discute a experiência com educação escolar gerada no interior do Movimento dos Trabalhadores Rurais Sem Terra - MST, efetuando uma análise do percurso da escola neste Movimento Social e uma divisão de sua história em períodos. Para essa periodização tomamos por base a revisão documental, a qual foi analisada em relação ao contexto mais amplo em que se movia o MST, apoiando-se ainda em dados de observações em escolas, encontros de formação e entrevistas. Para caracterizar como a questão escolar se constitui no MST o artigo propõe cinco períodos: "constituição da questão escolar", visível entre 1979 e 1991; "consolidação da proposta de escola" entre 1992 e 1995; "da escola à educação no MST" é um movimento que ocorre entre 1996 e os anos 2000; "massificação e 'crise' da escola" no período 2001 - 2006 e, por fim, entre 2007 a 2016 identificamos uma "retomada das elaborações sobre escola: radicalização na concepção, recuo nas lutas". O artigo conclui que o MST gesta, em meio a grandes limites e contradições, uma rica experiência de escola na perspectiva da classe trabalhadora, voltada à transformação social, o que inclui a transformação da própria escola. Indica ainda a existência de uma íntima articulação entre o conjunto das lutas deste Movimento e os papéis e objetivos atribuídos à escola, visíveis nos períodos assinalados.
\end{abstract}

Palavras-chave: Movimento dos Trabalhadores Rurais Sem Terra. Escola. História. Reforma Agrária.

\section{HISTORY OF SCHOOL WITHIN THE LANDLESS WORKERS MOVEMENT}

\begin{abstract}
The present study is about the experience with school education conducted within the Landless Workers Movement in Brazil (MST). This article analyses the trajectory of school within this Social Movement and divides its history into chronological periods. Such periodization was proposed based on a documental research, whose analysis considered a wider context in which MST operates and relied on data gathered from observation in schools, training meetings and interviews. To characterize how the school issue is constituted in the MST, five chronological periods are suggested: "composition of the school issue" noticeable between 1979 and 1991; "proposed consolidation of school" between 1992 and 1995; "From school to education in MST", which is a movement that occurred between 1996 and the 2000s, "School crisis and massification" between 2001 and 2006, and finally, between 2007 and 2016, there is a period of "resumption of elaborations about school:
\end{abstract}




\section{Revista HIIST'TEIDBR On-line}

radicalized conceptions, declining struggles". This article concludes that MST generates, amidst major limitations and contradictions, a valuable school experience from the perspective of the working class. It focuses on social transformation, which includes the transformation of the school itself. This study also suggests that there is a close link between all the struggles of this Movement and the roles and objectives assigned to school, which could be observed in the periods aforementioned. The main educational references of MST are Popular Education and Socialist Pedagogy, besides MST Pedagogy and Field Education.

Keywords: Landless Workers Movement (MST). School. History. Agrarian Reform.

\section{INTRODUÇÃO}

O Movimento dos Trabalhadores Rurais Sem Terra - MST é um dos mais importantes movimentos sociais na história brasileira, expressão da concentração da terra e da riqueza em um dos países mais desiguais do mundo. Ao longo de seus mais de trinta anos de história, a educação e a escola são objetos de atenção, resultando num vasto trabalho educacional poucas vezes visto entre movimentos de trabalhadores no Brasil. O MST constituiu uma vasta rede de escolas ligadas ao sistema público, que se localizam em áreas de influência do MST ou sob sua coordenação. Segundo dados do MST (MOVIMENTO SEM TERRA, 2010), existiam em suas áreas (assentamentos e acampamentos) cerca de duas mil e quinhentas escolas. Destas, 250 tem educação fundamental completa e apenas cinquenta possuem o ensino médio. Há aproximadamente 300 mil pessoas estudando em escolas públicas, da infância à Universidade, passando pela Educação de Jovens e Adultos (EJA). Quanto aos professores, nas escolas dos assentamentos e acampamentos atuam dez mil, sendo que mais de quatro mil professores foram formados no Movimento e existem parcerias com cinquenta instituições de ensino superior, e cerca de cem turmas de cursos formais. Na EJA o número de turmas organizadas pelo MST era em 2010 de quase mil e o total de educandos em torno de dez mil.

O presente artigo propõe-se à análise do significado da experiência com educação escolar no MST, tendo por base a reconstituição do percurso da escola no interior desse Movimento Social. Para esta reconstituição histórica buscou observar como se relacionam luta por escola e luta pela Reforma Agrária, considerando-se o contexto em que se move o MST durante o período analisado. Corroboramos a ideia de que não é possível compreender a educação e a escola fora do contexto que as demanda. (FIGUEIRA, 1985). A educação é um processo complexo e não homogêneo resultante das estruturas e práticas sociais também contraditórias, cujo objetivo é formar o homem para determinada forma de vida social. Como afirmou Mészáros, "[...] nenhuma sociedade pode perdurar sem seu sistema próprio de educação". (2006, p. 263). Dessa maneira, as formas e os objetivos educacionais de qualquer sociedade se encontram sempre em relação íntima com seu modo de vida e, portanto, com suas relações de produção e de trabalho. Numa sociedade dividida em classes, carregada de perspectivas antagônicas, serão diversas as experiências educacionais produzidas e demandadas, faces distintas de uma mesma totalidade social contraditória. A experiência educacional e escolar do MST é mais amplamente compreendida neste contexto, quer de luta 
por melhores condições para inserção social, quer de luta para superação desta forma de sociedade.

Parte dos dados para composição de uma história da escola no MST provém de investigação realizada pela autora durante o doutoramento, sendo que as informações para uma análise da atualidade provêm de estudos recentes. A pesquisa tomou por base documentos produzidos no MST no período de 1990 a 2016. Cotejamos os documentos sobre escola com a trajetória do próprio MST, a qual pode ser identificada inclusive nos documentos da educação. Apoiamo-nos ainda em observações realizadas em escolas, depoimentos e entrevistas. Foram analisados 26 documentos do MST e Setor de Educação que se referem à escola, seguindo o ano de sua elaboração e/ou publicação, os quais se encontram devidamente referenciados nas tabelas apresentadas no texto.

A delimitação dos períodos pautou-se pelas concepções de educação e de escola e o foco da luta por escola. Considerou ainda as relações internas (no MST) e externas (do MST e Setor de Educação com a sociedade de modo geral), ou seja, a repercussão da proposta e da experiência educacional interna e externa também contribuiu para uma identificação mais abrangente dos movimentos teóricos e práticos da questão escolar. A distinção de tais momentos na trajetória educacional desse Movimento, ainda que possível não é algo simples, uma vez que identificamos continuidades nesse processo. Assim, a periodização não significa o fim de muitas características de um determinado momento, mas em geral sua incorporação em um novo, em que comparecem e enfatizam-se outros aspectos. No que diz respeito aos desafios postos para a periodização, Glénisson (1986) levanta dificuldades encontradas pelos historiadores para estabelecer uma periodização clara, como por exemplo, por quais critérios se pautar para a caracterização de uma determinada sociedade ou período: pelos aspectos tradicionais ou pelos inovadores? $\mathrm{O}$ autor indica que "[...] a complexidade da trama histórica" [...] "exige a flexibilização dos critérios de periodização", revelando-se fundamental "[...] o significado da mudança". (1986, p. 316).

Considerando a complexidade deste empreendimento, buscamos nos apoiar numa visão de totalidade (LUKÁCS, 1968) para a delimitação dos períodos propostos. O conjunto de dados nos levou a delimitar cinco períodos, a saber: 1979 a 1991; 1992 a 1995; 1996 a 2000; 2001 a 2006; 2007 até a atualidade. As datas assinaladas são referências, mas não indicam uma rigidez ou uma ruptura explicitamente demarcada entre um ano e outro, antes comportam certa maleabilidade. Nomeamos cada período de acordo com suas características e nos empenhamos em desenvolvê-las, situando-as no contexto geral das lutas do MST à época. Construímos quadros-sínteses de cada um desses momentos, com destaque para os documentos analisados, os quais constam no início de cada período proposto.

\section{PRIMEIRO PERÍODO: CONSTITUIÇÃO DA QUESTÃo ESCOLAR NO MST}

Quadro 1 - Primeiro Período: Constituição da questão escolar no MST

(continua)

Concepções: necessidade da escola e escola como necessidade da luta

\begin{tabular}{|l|l|l|l|}
\hline MST - Contexto & Ano & Acontecimentos & Publicações/Documentos \\
\hline & 1979 & Primeiras ocupações de terra & \\
\hline
\end{tabular}


Quadro 1 - Primeiro Período: Constituição da questão escolar no MST

\begin{tabular}{|c|c|c|c|}
\hline \multirow{2}{*}{$\begin{array}{c}\text { Período } \\
\text { de constituição }\end{array}$} & 1980 & Primeiras atividades com crianças & \\
\hline & 1981 & & \\
\hline \multirow[t]{2}{*}{ do MST. } & 1982 & $\begin{array}{l}\text { Primeira escola construída em } \\
\text { acampamento, mas só legalizada } \\
\text { em } 1984 \text { no assentamento }\end{array}$ & \\
\hline & 1983 & & \\
\hline Foco: acesso à & 1984 & $\begin{array}{l}\text { Fundação do MST } \\
\text { Legalização da primeira escola em } \\
\text { assentamento }\end{array}$ & \\
\hline \multirow{2}{*}{$\begin{array}{l}\text { criar/consolidar } \\
\text { o Movimento. }\end{array}$} & 1985 & $\begin{array}{l}\text { Iniciam discussões no MST sobre a } \\
\text { educação e escola }\end{array}$ & \\
\hline & 1986 & $\begin{array}{l}\text { Primeira escola oficializada em } \\
\text { acampamento }\end{array}$ & \\
\hline \multirow[b]{2}{*}{$\begin{array}{c}\text { Lema: "Terra } \\
\text { para }\end{array}$} & 1987 & $\begin{array}{l}\text { Realiza-se o } 1^{\circ} \text { Encontro Nacional } \\
\text { de Educação }\end{array}$ & \\
\hline & 1988 & $\begin{array}{l}\text { Organização oficial do Setor de } \\
\text { Educação }\end{array}$ & \\
\hline \multirow[t]{3}{*}{$\begin{array}{l}\text { quem nela } \\
\text { trabalha!" }\end{array}$} & 1989 & \begin{tabular}{lcr}
\multicolumn{3}{l}{ III Encontro Nacional da Educação } \\
Primeiras & discussões & sobre \\
campanha & nacional & de \\
alfabetização de adultos & \\
\end{tabular} & \\
\hline & 1990 & $\begin{array}{l}\text { Curso de magistério na Fundep } \\
\text { Início das Cirandas Infantis }\end{array}$ & $\begin{array}{l}\text { CALDART, R. e } \\
\text { SCHAAB, B. (1990). } \\
\text { Nossa luta é nossa escola. }\end{array}$ \\
\hline & 1991 & $\begin{array}{lll}\text { Campanha } & \text { nacional } & \text { de } \\
\text { alfabetização } & \end{array}$ & $\begin{array}{l}\text { Caderno de Formação 18: } \\
\text { O que queremos com as } \\
\text { escolas de assentamento } \\
\text { (MST, 1991a). }\end{array}$ \\
\hline
\end{tabular}

Fonte: Elaboração da autora.

Assinalando o fim da ditadura militar, a primeira ocupação de terra ocorre nas Fazendas Macali e Brilhante em 1979, no estado do Rio Grande do Sul. Os primeiros registros de atividades com crianças são de 1981, na Encruzilhada Natalino (CALDART; SCHWAAB, 1990), num contexto em que as primeiras ocupações eram realizadas ainda sem uma articulação direta entre si, a depender da ebulição da questão social no campo e da conjuntura em cada local, contando com apoio da CPT. A partir de 1982 e 1983 é que se desenvolve uma articulação crescente entre os diversos focos de ocupação, culminando, em janeiro de 1984, com a fundação do MST que à época estava em organização em doze estados brasileiros. Trata-se de um período de articulação de uma nova fase da luta pela terra no Brasil, marcado pela busca de legitimação das ocupações de terra no contexto de pressão pela abertura democrática, o que incluía a busca de reconhecimento legal das escolas criadas nessas áreas. De qualquer modo, a inclusão da luta por escola no seio da luta pela terra aponta uma percepção mais abrangente, por parte dos acampados, do processo que estão desenvolvendo, da sintonia da luta específica com os desafios do momento histórico. Lutar 


\section{Revista HIIST'TEIDBR On-line}

pela terra é central, mas não suficiente. É preciso buscar as condições que permitam permanecer na terra, o que inclui lutar para mudar o que impede a permanência nela e a vida com dignidade.

O que consta em documentos históricos e falas de membros do MST e Setor de Educação, é que a luta por escola decorre de uma necessidade muito concreta das famílias acampadas e pode ser objetivamente atribuída a dois fatores: a existência de crianças em idade escolar nos acampamentos e a longa duração destes. A constituição dos acampamentos é determinada pela extrema pobreza dos sem terra, cuja luta envolve diretamente a família toda, diferentemente do sindicato ou partido. Daí a existência de muitas crianças em idade escolar nos acampamentos, cuja permanência por meses ou mesmo anos, levantava a questão: o que fazer com elas? O registro das primeiras atividades com crianças mostra que o objetivo inicialmente não era trabalhar a dimensão escolar, mas ajudá-las a compreender a situação em que viviam, ocupar-lhes o tempo e repassar informações básicas, que passaram a incluir aspectos da escolarização. (CALDART; SCHWAAB, 1990). Desses fatores origina-se a preocupação com a educação escolar, antes mesmo da criação do MST.

Para os sem terra, a questão escolar nasce nos acampamentos. Depois, com a desapropriação das primeiras áreas, será uma preocupação também para os assentamentos, mas isso ocorrerá a partir de 1985/86, já acumulando certo número de áreas destinadas à Reforma Agrária.

Este momento inicial é marcado por duas concepções de escola: a "necessidade da escola" e a "escola como necessidade de luta". A primeira é entendida como uma condição de acesso aos bens culturais produzidos socialmente, já a "escola como necessidade da luta" expressa a visão dessa instituição por outra perspectiva política, qual seja, da transformação social e de mudanças na escola.

Assim, a força maior que faz a escola entrar na luta do MST decorre da preocupação das famílias e também das coordenações dos acampamentos com o "estudo" das crianças, com a noção do direito e do dever de ir à escola para buscar um futuro melhor. O texto que segue ilustra esta questão: "neste acampamento [Nova Ronda Alta, RS, 1982] eram 180 crianças em idade escolar, sendo 112 delas para ingresso na $1^{a}$ série, ou seja, prontas para serem alfabetizadas. Isso começou a preocupar seriamente os pais". Duas professoras ligadas ao acampamento passam a "[...] articular entre os acampados a luta pela criação de uma escola estadual de $1^{\mathrm{a}}$ a $4^{\mathrm{a}}$ séries, no acampamento". (CALDART; SCHWAAB, 1990, p. 12). Para os autores, "A importância dessa iniciativa era não deixar as crianças completamente paradas, embora as aulas não valessem como ano letivo". (1990, p. 25). As escolas também eram criadas nos acampamentos tendo em vista a realização dos assentamentos. Dessa forma, a luta por escola não nasce fundamentalmente da consciência de classe das famílias acampadas, mas antes da busca por melhores condições de vida aos filhos. Todavia, cada vez mais, para o MST, a escola será assumida como articulada ao seu projeto de sociedade. Veremos, entretanto, como o valor da escolarização, ainda que não tenha deixado de estar presente ao longo de toda a trajetória do MST, será retomado com mais força em um período recente.

Outro aspecto que se soma à dificuldade de separação cronológica das duas concepções assinaladas é o fato de que as primeiras atividades realizadas com crianças, anteriormente à própria existência de escola em acampamentos e que lhe servirão de 
impulso, já possuía um claro caráter político-pedagógico: “[...] são formados grupos de mães, que passam a orientar as brincadeiras do grupo de crianças e a explicar, pelo menos um pouco, o que está acontecendo em suas vidas, integrando-as nas várias atividades do acampamento". (CALDART; SCHWAAB, 1990, p. 12). Dessa forma, podemos entender que, ainda que as inserções políticas a respeito da escola estivessem presentes desde seu início, o estão de forma pontual e não constituem o elemento desencadeador fundamental da existência de escola nessas áreas.

O que ajudará a apontar para uma "escola diferente" serão as necessidades da luta concreta empreendida pelo MST. A escola precisa ser um espaço sintonizado no contexto do movimento, as crianças precisam aprender, inclusive na escola, o porquê de estarem ali, a luta de seus pais. Aos poucos vai se configurando "[...] uma escola que deveria valorizar a história de luta dessas famílias, ensinando a ler e a escrever através de experiências que também desenvolveram amor à terra e ao trabalho". (CALDART; SCHWAAB, 1990, p. 13). Vemos aqui a força da educação formal, sistemática e planejada. Vemos também que a (re) politização da escola, proporcionada pelo MST, decorre de circunstâncias objetivas e necessidades concretas da luta. A isso chamamos "escola necessária à luta". É o que buscamos marcar aqui: a proposta de educação não é fruto de imposições ideológicas, antes decorre da necessidade de sobrevivência das famílias e depois de sobrevivência da própria luta e sua organização.

No período que vai das primeiras ocupações (1979 - 1980) até mais da metade dessa década, as duas concepções presentes de escola, a "necessidade da escola" e a "escola necessária à luta", coexistem, misturam-se. Há predomínio de uma ou de outra em cada acampamento de acordo com o estágio da luta em cada local. É para discutir a necessidade da escola e como fazê-la de modo diferente, fruto do acúmulo de alguns anos, que em 1988 é constituído o Setor de Educação. Este nasce com a tarefa vinculada às escolas de $1^{\mathrm{a}}$ à $4^{\mathrm{a}}$ série nos acampamentos e assentamentos, o que posteriormente se ampliará.

No final dos anos 1980, quando a escola já está claramente articulada à luta dos sem terra, começam a se estabelecer vínculos entre a escola, os propósitos do MST e a realização da Reforma Agrária. Nos primeiros escritos (1990 e 1991) que tratam da escola, esta aparece como orgânica ao MST, como espaço e instrumento de luta. Entende-se que os conflitos em torno da terra precisam ser trabalhados pela escola e que o grande desafio desta passa a ser vincular o conhecimento e o processo educacional à organização dos assentamentos, às formas de trabalho e organização. (CALDART; SCHWAAB, 1990).

As referências pedagógicas principais do período são a Pedagogia do Oprimido de Paulo Freire e as experiências de Educação Popular que orientam sobretudo o trabalho com alfabetização de adultos nos acampamentos. As obras de Pistrak e Kruspkaya também são estudadas nos cursos de formação de professores, mas segundo depoimentos, a base freiriana acaba por prevalecer na orientação às escolas devido à proximidade geográfica, política e pedagógica com o autor e pela complexidade da experiência russa.

Os princípios pedagógicos indicados à época são o trabalho e a organização coletiva como valores educativos fundamentais; a integração da escola na organização do assentamento; a formação integral da criança; a democracia como parte essencial do processo educativo; a integração do professor na organização do assentamento; a construção de um projeto alternativo de vida social; metodologia baseada na concepção dialética do 
conhecimento. Sublinha ainda a necessidade de a escola produzir as bases dos conhecimentos científicos mínimos necessários para o avanço da produção e da organização nos assentamentos e o fortalecimento da relação entre escola, assentamento e MST. (MOVIMENTO SEM TERRA, 1991a, p. 51). Vemos que esse documento já contém as bases da proposta de educação escolar do Movimento que será melhor consolidada no momento seguinte.

\section{SEGUNDO PERÍODO: CONSOLIDAÇÃO DA PROPOSTA DE ESCOLA}

Quadro 2 - Segundo período: consolidação da proposta de escola no MST

\begin{tabular}{|c|c|c|c|}
\hline \multicolumn{4}{|c|}{ Concepções: escola de assentamento / escola do trabalho } \\
\hline $\begin{array}{c}\text { MST - } \\
\text { Contexto }\end{array}$ & Ano & Acontecimentos & Publicações/Documentos \\
\hline \multirow{2}{*}{$\begin{array}{c}\text { Consolidação e } \\
\text { nacionalização do } \\
\text { Movimento. } \\
\text { Foco: } \\
\text { desenvolvimento } \\
\text { dos assentamentos } \\
\text { e cooperação. }\end{array}$} & 1992 & $\begin{array}{l}\text { V Encontro Nacional de } \\
\text { Professores de Escolas de } \\
\text { Assentamentos, em parceria } \\
\text { com outras instituições. } \\
\text { Realizam-se grupos de } \\
\text { trabalho (oficinas) }\end{array}$ & $\begin{array}{l}\text { Boletim de Educação 1: Como } \\
\text { deve ser a escola de um } \\
\text { assentamento (MST, 1992a). } \\
\text { Caderno de Educação 1: Como } \\
\text { fazer a escola que queremos } \\
\text { (MST, 1992b). }\end{array}$ \\
\hline & 1993 & $\begin{array}{l}\text { Início do Curso Técnico em } \\
\text { Administração de } \\
\text { Cooperativas } \\
\end{array}$ & $\begin{array}{l}\text { A importância da prática na } \\
\text { aprendizagem das crianças } \\
\text { (MST, 1993). }\end{array}$ \\
\hline $\begin{array}{l}\text { Lema: "Ocupar, } \\
\text { resistir e } \\
\text { produzir!" }\end{array}$ & 1994 & $\begin{array}{l}\text { I Encontro Sem Terrinha } \\
(\mathrm{RS})\end{array}$ & $\begin{array}{l}\text { Boletim de Educação 4: } \\
\text { Escola, Trabalho e Cooperação } \\
\text { (MST, 1994). } \\
\text { Diversos cadernos de EJA. }\end{array}$ \\
\hline & 1995 & $\begin{array}{l}\text { Inauguração do Iterra }{ }^{2} \text {. } \\
\text { MST recebe Prêmio Itaú- } \\
\text { Unicef pelo trabalho na } \\
\text { educação. }\end{array}$ & $\begin{array}{l}\text { Boletim de Educação 5: O } \\
\text { trabalho e a coletividade na } \\
\text { educação (Makarenko, apud } \\
\text { MST, 1995a). } \\
\text { Texto: Ensino de } 5^{\text {a a }} 8^{\text {a }} \text { série } \\
\text { em áreas de assentamento } \\
\text { (MST, 1995b) }\end{array}$ \\
\hline
\end{tabular}

Fonte: Elaboração da autora.

A criação e a estruturação de assentamentos foram se concretizando no decorrer da década de 1980. Em 1990 já somavam 730, com mais de cem mil famílias em cinco milhões de hectares. (CONDE, 2004). No final dos anos 1980, intensificam-se as discussões em torno da organização coletiva dessas áreas e em 1990 é criado o Sistema Cooperativista dos Assentados - SCA. Naquele ano também foram realizados convênios para assistência técnica. Realiza-se o II Congresso Nacional do MST com o lema "Ocupar, resistir e produzir", que indicava, além da manutenção da principal forma de luta - a ocupação e a 


\section{Revista HIIST'TEIDBR On-line}

necessidade de resistir ao governo Collor que enfaticamente combatia as ocupações. Mas também indicava a força da dimensão da produção dos assentamentos, cuja organização coletiva é apontada como principal alternativa de organização da produção e do conjunto da vida para as áreas conquistadas. Em 1992 já se contavam mais de vinte cooperativas e em 1994 eram 53, com sete centrais estaduais e centenas de associações. (CONDE, 2004). Todavia, já a partir de 1992 começam a aparecer dificuldades nos coletivos e cooperativas que, junto a outros fatores, comporão mais enfaticamente, a partir de 1995, uma crise na forma de organização e produção dos assentamentos, resultando em fragilização e relativização crescente da forma cooperada.

O setor de educação mantém como foco as séries iniciais de ensino fundamental, lentamente se estendendo para as séries finais, que em 1995 ganham um Caderno de Educação específico. A educação infantil a partir de 1990 integra o trabalho do Setor de Educação, mas ainda de modo pontual e inicial e as ações em EJA são fortalecidas. No período em foco, o acompanhamento direto às escolas pelo setor de educação dos estados será enfático, além de atividades para capacitação de professores, na maioria informal. A repercussão da proposta de educação, nas escolas, em meados da década de 1990, será a maior já alcançada. Um aspecto importante para isso foi a adesão de muitos professores à luta do MST, os quais somavam sua experiência e formação profissional à militância, qualificando o trabalho desenvolvido e irradiando notícias de seus trabalhos por outros locais. Em 1995 o MST ganha o prêmio Itaú- Unicef por seu trabalho educacional. Naquele ano somavam cerca de 750 escolas, 35 mil crianças e 1400 professores. (CONDE, 2004).

A produção teórica em torno da escola no período acima caracterizado foi vasta, constituindo-se, em nosso entendimento, em um dos momentos mais férteis de formulação da proposta educacional do MST. Naquele momento efetivamente delineou-se uma proposta de escola expressa em vários documentos, como se vê no Quadro 2. Para captar a essência da proposta para a escola nesse período, já claramente posta desde o primeiro documento do MST, utilizamos da síntese apresentada no Boletim de Educação n. 1 (MOVIMENTO SEM TERRA, 1992a, p. 2): "[...] os três pilares fundamentais da escola dos Assentamentos devem ser: o trabalho agropecuário, o conhecimento científico da realidade e amor pela luta". Estão apresentados aí os três grandes objetivos da escola para o MST, que podem ser entendidos como síntese de sua perspectiva para com a escola desde a época da publicação até a atualidade: a preparação para o trabalho no campo, a escolarização e a formação de militantes.

Do conjunto dos documentos analisados nesse período, ganha destaque o Boletim n. 4 Escola, Trabalho e Cooperação (MOVIMENTO SEM TERRA, 1994), texto de fundamentação teórica da proposta. O foco é a "escola de assentamento", a qual desenvolvese na forma de "escola do trabalho". Esta será uma espécie de resposta, no campo educacional, às dificuldades crescentes de organização do trabalho e da cooperação nos assentamentos. O Boletim busca refletir sobre as experiências de trabalho existentes, bem como sobre a formação para o trabalho, proporcionada nas escolas e cursos. A escola é vista como um espaço que pode ajudar a responder ao desafio da organização coletiva e à produção dos assentamentos. Entendendo o potencial educativo do trabalho, da prática social, argumenta que o trabalho é um dos pilares fundamentais da proposta de educação do MST. Propõe assim que as escolas de acampamento e assentamento sejam escolas do trabalho, "[...] quer dizer escola do trabalhador, da classe trabalhadora" (MOVIMENTO 
SEM TERRA, 1994, p. 4), em que "[...] o princípio educativo fundamental esteja no trabalho". (idem: ibidem, p. 10). O documento segue defendendo que a escola seja ligada à realidade concreta e ativa na solução dos problemas surgidos em seu meio, educando para a cooperação agrícola, preparando tecnicamente e desenvolvendo o amor pelo trabalho, especialmente do meio rural. O caderno indica a importância de trazer o trabalho para dentro da escola o que se justifica por este ser capaz de alterar a lógica da escola, e pelo fato de esta, por sua vez, contribuir para tornar as atividades das crianças e do assentamento mais educativas. Entende-se que "[...] se a escola conseguir proporcionar aos alunos uma experiência real de trabalho produtivo socialmente dividido, ela estará alterando ou educando a verdadeira consciência ou mentalidade coletiva". (MOVIMENTO SEM TERRA, 1994, p. 9, grifo do autor). Desse modo, não é qualquer trabalho que deve estar presente na escola, mas "[...] aquele que mistura cooperação com democracia", o que deve ser exercitado na própria escola.

O que transparece em três dos quatro últimos documentos (MOVIMENTO SEM TERRA, 1993, 1994, 1995b) é a necessidade de a escola contribuir especialmente com as formas de trabalho dos assentamentos, uma vez que o projeto do MST encontra muitas dificuldades para ser implementado, então a educação é chamada para ajudar a alterar a realidade dessas áreas. Se no início do período em pauta e mesmo no anterior a escola é chamada para somar-se a um projeto em construção, sintonizando-se com a luta desenvolvida pelo MST, agora altera-se ligeiramente este quadro: à escola é reservado um importante papel de auxiliar e impulsionar o projeto porque ele encontra dificuldade para avançar. Cria-se assim uma grande expectativa para com a escola e os cursos de formação. Como veremos adiante, em situações de dificuldade crescente na luta do MST, há maior aposta nas possibilidades formativas da escola, a qual, de modo algum, chega a ser vista como motor da luta. Este momento - final dos anos 1990 - também se caracteriza por maior explicitação do MST como parte da luta de classes, o que desembocará em um terceiro momento, delineado a seguir.

\section{TERCEIRO PERÍODO: DA ESCOLA À EDUCAÇÃO NO MST}

Quadro 3 - Terceiro Período: Da escola à educação no MST

\begin{tabular}{|c|c|c|c|}
\hline \multicolumn{4}{|c|}{ Concepções: Pedagogia do MST e Educação do Campo } \\
\hline $\begin{array}{c}\text { MST - } \\
\text { Contexto }\end{array}$ & Ano & Acontecimentos & Publicações/Documentos \\
\hline $\begin{array}{l}\text { Auge da luta } \\
\text { do MST: } \\
\text { marcha à } \\
\text { Brasília, }\end{array}$ & 1996 & $\begin{array}{l}\text { Convênio entre entidades ligadas ao } \\
\text { MST e MEC para alfabetização de } \\
\text { adultos. Aprovação da Escola } \\
\text { Itinerante no RS. }\end{array}$ & $\begin{array}{l}\text { Caderno de Educação 8: } \\
\text { Princípios da Educação no } \\
\text { MST (MST, 1996). }\end{array}$ \\
\hline $\begin{array}{l}\text { Massacre de } \\
\text { Eldorado dos } \\
\text { Carajás e }\end{array}$ & 1997 & $\begin{array}{l}\text { I ENERA - Encontro Nacional de } \\
\text { Educadores das áreas de Reforma } \\
\text { Agrária }\end{array}$ & \\
\hline
\end{tabular}




\section{Revista HIIS'TEIDBR (Dn-lime}

Quadro 3 - Terceiro Período: Da escola à educação no MST

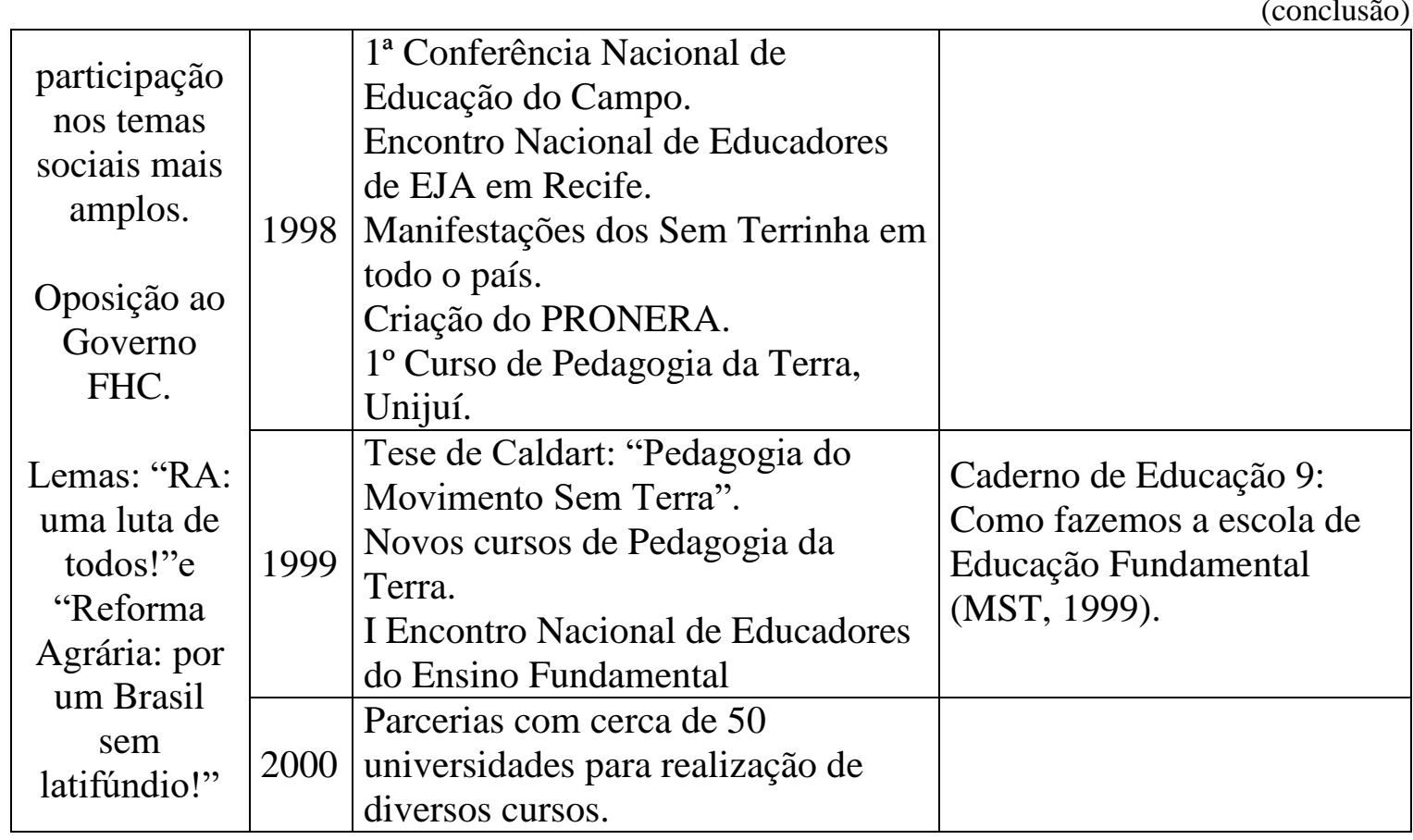

Fonte: Elaboração da autora.

Se internamente, na organização dos assentamentos, o MST enfrentava grandes dificuldades, de outro lado, por sua capacidade mobilizadora de famílias para os acampamentos, bem como por sua referência de organização, disciplina e mística, conquistou muitos setores organizados da classe trabalhadora. Além do mais, o Movimento havia resistido a períodos muito difíceis e encontrava agora um contexto político um pouco mais ameno. O III Congresso Nacional realizado em 1995 com o lema "Reforma Agrária: uma luta de todos!" Expressa o apelo à classe trabalhadora brasileira para que se una ante a correlação de forças no campo que não permite realizar a Reforma Agrária; esta depende do apoio e organização do conjunto da população do país. O tema da Reforma Agrária, visto por alguns como ultrapassado, é retomado com força, demonstrando um país com imensas desigualdades sociais, a população do campo diminuindo e empobrecendo, contrastando com a permanência do latifúndio. Este se apresenta sob nova roupagem, o agronegócio, subsidiado pelas políticas de Estado. O MST será fortemente combatido durante o governo Fernando Henrique Cardoso, especialmente em seu segundo mandato, em que o Movimento foi um dos seus mais enfáticos oponentes. 1996 foi o ano do Massacre de Eldorado Carajás. Em 1997 é realizada a Marcha Nacional pela Reforma Agrária que chega a Brasília reunindo cerca de cem mil pessoas. A realização da Reforma Agrária tem apoio de mais de $85 \%$ da população brasileira, segundo pesquisas realizadas à época. O Movimento passará a se posicionar em importantes debates da política nacional como privatizações, Vale do Rio Doce, transgênicos, eleições, entre outros. Em 2000, o V Congresso do MST com o lema "Reforma Agrária por um Brasil Sem Latifúndio" expressa o MST pensando a nação desde o campo.

Existem mais de mil escolas em assentamentos e 120 mil pessoas estudando. O Iterra, criado em 1995, consistia em um espaço de formação de militantes, profissionais e 


\section{Revista HIIST'TEIDBR On-line}

laboratório da experiência de educação do MST, motivando a criação de outras escolas e centros de formação. A partir de 1998 desenvolvem-se parcerias com Universidades para cursos de Pedagogia. Fruto da pressão e força do trabalho educacional é criado o PRONERA Programa Nacional de Educação na Reforma Agrária- em pleno governo FHC, a partir do qual foi ampliada a atuação do Movimento na educação de jovens e adultos e posteriormente em cursos diversos de nível médio e superior. Em 1998, realiza-se a primeira Conferência por uma Educação Básica do Campo.

O Caderno dos Princípios da Educação no MST (MOVIMENTO SEM TERRA, 1996) é um marco na trajetória que estamos discutindo porque assinala um momento em que o trabalho do setor se expandiu para além da escola primária de acampamento e assentamento. A noção de escola é alargada, incluindo também o nível médio, a educação infantil, a educação de jovens e adultos, os cursos técnicos, a formação de educadores, formais ou informais. Apontamos, a seguir, as ideias que ainda não haviam sido explicitadas ou a ênfase que recebem devido ao salto de qualidade.

A primeira delas refere-se ao reconhecimento explícito de que a educação no MST precisa contribuir com a luta de classes, ou seja, "[...] uma educação que se organiza, que seleciona conteúdos, que cria métodos na perspectiva de construir a hegemonia do projeto político da classe trabalhadora". (MOVIMENTO SEM TERRA, 1996, p. 6). Outro aspecto é a educação massiva, ou a educação como direito de todos. A "educação voltada para as várias dimensões da pessoa humana", ou educação omnilateral, ainda que anunciada de formas distintas em outros documentos, adquire solidez e concretude nesse caderno, lançando bases para um aspecto que passará a ser mais explorado a partir de então. A atuação da escola nas várias dimensões humanas, ou na sua totalidade, se tornará bastante concreta através dos tempos educativos, ideia que será bastante difundida posteriormente. A noção de que as pessoas estão em formação permanente também adquire força à medida que o trabalho com educação passa a atingir jovens adultos e idosos de forma crescente. A educação para novos valores, que exercite a ética, continua presente, mas agora adjetivada com termos que afirmam a perspectiva socialista.

A partir de 1998 tem entrada no MST um novo debate: a Educação do Campo, que se estende até hoje e deixará marcas na perspectiva de educação do Movimento. O MST está articulado à Via Campesina. Os conceitos de campo e campesinato são retomados, apontando que há uma cultura, um modo de vida camponês que deve ser respeitado e em certa medida retomado como forma de assegurar a sobrevivência da população campesina, de preservar a biodiversidade existente no país, promovendo um desenvolvimento social, econômico e ambientalmente sustentável. Na educação iniciam-se as articulações em torno de uma proposta de educação para os povos do campo e em 1998 é realizada a I Conferência Nacional por uma Educação Básica do Campo, aglutinando movimentos sociais, universidades, ONG's e secretarias de educação parceiras. Outras conferências se seguirão, serão criadas articulações nos estados e departamentos específicos em secretarias de educação simpáticas à causa. Em 2003, no Governo Lula foi criado um Grupo de Trabalho sobre a Educação do Campo. Se de um lado a educação no MST deixou de pensar mais concretamente a vida e o trabalho no assentamento no período entre 1996-98, com a Educação do Campo, esta preocupação retorna, mas agora debruçando-se sobre a cultura, o trabalho e os sujeitos do campo. A luta por políticas públicas educacionais também será a 
tônica do Movimento por uma Educação do Campo que influenciará a perspectiva educativa do MST.

Em 1999, Roseli Salete Caldart, integrante do Setor de Educação, defende tese de doutorado, cuja ideia fundamental é de que o Movimento Sem Terra possui uma pedagogia, um modo próprio de educar os sujeitos que o compõem, potencialmente conformador da identidade Sem Terra.

É ele o sujeito educativo principal do processo de formação dos sem-terra, no sentido de que por ele passam as diferentes vivências educativas de cada pessoa que o integra, seja de uma ocupação, um acampamento, um assentamento, uma marcha, uma escola. Os sem-terra se educam como Sem Terra (sujeito social, pessoa humana, nome próprio) sendo do MST, o que quer dizer construindo o Movimento que produz e reproduz sua própria identidade ou conformação humana e histórica. (CALDART, 2004, p. 315, grifo do autor).

A Pedagogia do Movimento será a orientadora dos debates e proposições do Setor de Educação, e dará o tom das duas seguintes publicações, o Caderno de Educação $\mathrm{n}^{\circ}$ 9: Como Fazemos a Escola de Educação Fundamental (MOVIMENTO SEM TERRA, 1999), e o Boletim da Educação 8: Pedagogia do Movimento Sem Terra. (MOVIMENTO SEM TERRA, 2001a). No Caderno de 1999, a escola é concebida como espaço onde reflexões sobre a Pedagogia do MST devem ser realizadas, extraindo-se dela "[...] as 'lições de pedagogia' que permitem fazer (e transformar), em cada escola, o movimento pedagógico que está no processo de formação da identidade dos sujeitos Sem Terra, como também na formação dos sujeitos humanos, de modo geral". (1999, p. 6). Assim, as matrizes educativas fundamentais que o MST aciona na educação dos Sem Terra precisam se fazer presentes na escola, tornando-as conteúdos de estudo e educando para seus valores e relações. Esse Caderno explicita um tipo de escola na qual a estrutura orgânica está embasada na forma de organização dos acampamentos, com princípios de gestão democrática e auto-organização dos estudantes, na construção de um ambiente educativo com diferentes tempos, como aula, trabalho, oficina, esporte/lazer, estudo, cujas relações devem ser pautadas pela luta, mística, ecologia, entre outros. $\mathrm{O}$ trabalho/produção aparece com importância para os estudantes na escola e da relação desta com o trabalho realizado na família e com outras formas de trabalho. O estudo deve ter como objetivo o "[...] máximo envolvimento dos educandos na produção do conhecimento". (1999, p. 42).

No Caderno de Educação n. 9 (MOVIMENTO SEM TERRA, 1999) e no Boletim de Educação n. 8 (MOVIMENTO SEM TERRA, 2001a) a escola é concebida como espaço com atuação sobre a complexidade do ser humano, educando-o em múltiplas dimensões. A escola é uma "[...] oficina de formação humana", cujo "[...] processo de desenvolvimento humano acontece de modo intencionalmente planejado, conduzido e refletido para isso." E que é preciso "[...] planejar estratégias pedagógicas diversas, em vista dos diferentes aprendizados que compõem o complexo processo de formação humana". (MOVIMENTO SEM TERRA, 2001a, p. 48).

A noção de produção do conhecimento passa a predominar sobre a ideia de acesso ao conhecimento e à ciência como era anunciado nas primeiras formulações. $\mathrm{O}$ papel historicamente atribuído à escola no desenvolvimento intelectual, cognitivo, não é destacado, enquanto se acentuam outras dimensões, como transparece nesses documentos. 
A escola passa a ser enfatizada como um dos espaços de educação permanente, de aprendizagens coletivas, que deve aprender com o MST, que exercite a democracia nas relações, mas pouco enfatiza suas funções de ensinar, de possibilitar o acesso à cultura e ao saber elaborado.

Por fim, nos textos analisados, parece-nos haver uma crença exacerbada na escola como capaz de formar omnilateralmente, como local privilegiado na formação do novo homem (ainda que no MST essa função não seja apenas reservada à escola). A formação integral e os novos valores devem perpassar pelo trabalho escolar, mas não é possível atingir tal pretensão nesse espaço se a vida fora da escola continua pautada na divisão do trabalho em classes sociais. Não é possível atribuir à escola a formação para o trabalho e para valores sob novas bases se a materialidade nos assentamentos a contradiz.

É visível no percurso histórico da educação no MST, marcadamente no período ora em questão, de um lado, um salto de qualidade na proposta escolar, que vê a escola como um dos espaços de educação, que amplia suas funções formativas e as articula à luta de classes, de outro, aparece maior ecletismo teórico cujas implicações serão evidentes no momento seguinte. Também, nesse período, a proposta em gestação não foi traduzida em metas mais concretas que parecessem viáveis às pessoas envolvidas em sua construção na base do Movimento. Os professores asseveravam tratar-se de uma escola ideal, a qual até desejavam, mas que não podia ser concretizada na realidade em que se encontravam. ${ }^{3}$ Os documentos do Setor de Educação já não chegarão a todas as escolas e em muitas não despertarão interesse e compreensão, enfim, seu potencial orientador diminuiu muito proporcionalmente às unidades existentes. Enfim, se o Caderno dos Princípios e Pedagogia do MST são marcos no amadurecimento da proposta de educação e de escola, também assinalam o início de um período em que a escola é tomada de um modo bastante generalizado e abstrato, deixando de falar concretamente com a grande massa de escolas do Movimento, culminando em um quarto período.

\section{QUARTO PERÍODO: MASSIFICAÇÃO E “CRISE" DA ESCOLA}

Quadro 4 - Quarto Período: Massificação e "crise” da escola.

\begin{tabular}{|c|c|c|c|}
\hline \multicolumn{4}{|c|}{ Concepção: Todo Sem Terra Estudando } \\
\hline MST- Contexto & Ano & Acontecimentos & Publicações/Documentos \\
\hline \multirow{4}{*}{$\begin{array}{c}\text { Eleição de } \\
\text { Lula. } \\
\text { Políticas de } \\
\text { governo, mas a } \\
\text { questão } \\
\text { essencial não } \\
\text { avança. }\end{array}$} & 2001 & & $\begin{array}{l}\text { Os desafios do Setor de } \\
\text { Educação. IN: Construindo o } \\
\text { Caminho (MST, 2001). } \\
\text { Boletim da Educação 8: } \\
\text { Pedagogia do Movimento } \\
\text { Sem Terra (MST 2001a). }\end{array}$ \\
\hline & 2002 & & \\
\hline & 2003 & & \\
\hline & 2004 & $\begin{array}{l}2^{\text {a }} \text { Conferência Nacional de } \\
\text { Educação do Campo. }\end{array}$ & \\
\hline
\end{tabular}




\section{Revista HIIST'TADBR On-line}

Quadro 4 - Quarto Período: Massificação e "crise” da escola.

\begin{tabular}{|c|c|c|c|}
\hline $\begin{array}{l}\text { Criminalização } \\
\text { do } \\
\text { Movimento. } \\
\text { Lema: }\end{array}$ & 2005 & $\begin{array}{l}\text { Coordenação Nacional do MST } \\
\text { discute a Educação no } \\
\text { Movimento. }\end{array}$ & $\begin{array}{l}\text { Síntese da discussão da } \\
\text { Coordenação Nacional (MST, } \\
\text { 2005). } \\
\text { Caderno de Educação 13: } \\
\text { Dossiê MST Escola (MST, } \\
\text { 2005a). }\end{array}$ \\
\hline $\begin{array}{l}\text { "Reforma } \\
\text { Agrária: por } \\
\text { um Brasil sem } \\
\text { latifúndio!" }\end{array}$ & 2006 & $\begin{array}{l}\text { Seminário Nacional de } \\
\text { Educação Média. }\end{array}$ & $\begin{array}{l}\text { Documento Final do } 1^{\circ} \\
\text { Seminário Nacional sobre } \\
\text { Educação Básica de Nível } \\
\text { Médio (MST, 2006). }\end{array}$ \\
\hline
\end{tabular}

Fonte: Elaboração da autora.

Se o período anterior, acima analisado, expressou o auge da luta política alcançado pelo MST, ainda que enfrentasse grandes dificuldades internas na organização dos assentamentos, o período atual, caracterizado pela massificação e o surgimento da "crise da escola", é de menor articulação na luta pela Reforma Agrária entre as organizações de esquerda. A difamação do MST pela mídia conseguiu produzir certa indiferença ou omissão de alguns setores da população para com o MST e a causa da reforma agrária. Isso ocorreu no período pré e pós eleição de Lula, a qual é um marco para a luta do MST. Se por um lado esse governo foi marcado por menor repressão às organizações de trabalhadores e maior entrada destas às esferas administrativas, de outro foi deixando claros os limites da disputa eleitoral e do aparato de Estado para alcançar conquistas mais significativas aos trabalhadores. No caso da Reforma Agrária isso é patente. A pauta do MST foi atendida em aspectos muito pontuais, enquanto as questões vitais como realização massiva de assentamentos, política agrícola, assistência técnica, educação, transgênicos, foram continuamente adiados até desvanecer-se a perspectiva de realização por parte do governo. Ao contrário, o governo Lula revelou-se entusiasta do agronegócio. Nesse período o grande capital fundiário consolidou a hegemonia da agricultura, revertendo a condição do período anterior no qual o setor sofreu uma derrota política com o questionamento social e econômico do latifúndio. Este novo quadro colocou condições delicadas para o MST no embate político nacional. Mesmo setores da esquerda no campo aderiram à perspectiva empresarial para a agricultura. Outros setores organizados da classe trabalhadora viram sua condição regredir em pleno governo do Partido dos Trabalhadores, como as centrais sindicais que perderam o que havia de radicalidade na ação. O MST que já há alguns anos articulava sua ação com os setores de esquerda urbana e do conjunto do país, depara-se com um contexto de refluxo das organizações aliadas bem mais abrangente e complexo do que no período anterior, cuja oposição à Fernando Henrique Cardoso garantia maior unidade às lutas. O resultado dessa matemática política internamente para o MST só poderia significar a necessidade do fortalecimento de sua organização. Identifica-se, a partir dos anos 2000, uma retomada dos debates acerca da forma de vida e de produção nas áreas conquistadas e, por consequência, do papel da escola nessas áreas. Em 1999 define-se que a agroecologia deve ser a diretriz orientadora da forma de produção dos assentamentos.

Durante o governo Lula, ampliaram-se os programas sociais que tinham os assentados como público beneficiário, especialmente na área da educação e produção. 


\section{Revista HIIST'TEIDBR On-line}

Também se ampliaram as articulações com universidades e com o movimento da Educação do Campo, o que no conjunto significou uma dispersão das ações educacionais, especialmente em relação ao grande contingente de escolas nas áreas de assentamento. Isso significou que, se o volume de trabalho do setor cresceu e se ampliou, diminuiu significativamente a capacidade de influir concretamente nas escolas. Em 2004 o MST possuía em suas áreas mais de 1800 escolas, 160 mil crianças estudando, cinco mil educadores. Na educação infantil tinha-se em torno de500 educadores e na EJA mais de 30 mil estudantes. Nesse período se ampliará vertiginosamente a quantidade de cursos formais organizados pelo MST em parceria com instituições educacionais e em sua maioria com apoio do PRONERA. Em cursos formais médios e profissionalizantes existiam em 2004 cerca de 1500 estudantes e em universidades cerca de 750. (CONDE, 2004). A síntese deste processo é a chamada "[...] para ser Sem Terra é preciso estar estudando". (MOVIMENTO SEM TERRA, 2005). Os cursos na área da educação irão desde a alfabetização e escolarização de jovens, adultos e idosos, Cursos de nível médio (Normal) e Pedagogia da Terra, Especializações em Educação do Campo, até cursos de licenciatura em diferentes áreas de formação e atividades de formação diversas sem escolarização. Os da área da produção serão basicamente de médio e pós médio em agroecologia ou afins, agronomia, além de cursos de especialização.

Esse quadro conferia ao MST grande capacidade mobilizadora no campo educacional. Amplia-se o número de unidades da federação que legalizavam a Escola Itinerante $^{4}$, melhorando suas condições de infraestrutura física, de pessoal e formação pedagógica. Mas esta não era a realidade das escolas de assentamentos, as quais se viam extremamente submetidas aos governos, especialmente os municipais, contavam com um quadro de professores extremamente rotativo e pouco disposto a mudar o trabalho pedagógico, além da desarticulação das comunidades. A capacidade mobilizadora do MST e a solidez de sua proposta de educação revelaram-se bastante frágeis diante da dureza surda da escola formal e do sistema oficial de ensino. Enfim, no período em que a busca por escolarização e capacitação receberá maior ênfase por parte do MST, será paradoxalmente nele que haverá menor diálogo e influência nas milhares de escolas existentes em assentamentos, aprofundando o distanciamento destas em relação às orientações teóricometodológicas do MST, o que vinha ocorrendo desde períodos anteriores. Como nunca em sua história, o MST teve experiências de ocupação da escola, escolarizando, formando militantes e profissionais, mas também como nunca as escolas de assentamentos se viram tão carentes de reflexões e orientações e de uma proposta mais concreta. Esta análise está evidente no Boletim de Educação n. 9, o qual, fazendo um balanço da educação nos vinte anos de existência do MST indica: “[...] em relação às escolas públicas que conquistamos, mais avançamos na concepção a partir de experiências pontuais do que mexemos significativamente no conjunto das escolas". (MOVIMENTO SEM TERRA, 1999, p. 14).

Entendemos que o distanciamento do MST para com as escolas de assentamento precisa ser compreendido como componente da crise de perspectiva na organização dessas áreas. Isso é capaz de explicar porque um momento tão favorável internamente às questões educacionais coincide com a falta de políticas mais concretas para a escola nesses locais, o que reflete uma crise de perspectiva na organização dos próprios assentamentos.

Nesse quadro, a Pesquisa Nacional da Educação nas Áreas de Reforma Agrária PNERA $^{5}$, realizada em 2004, trouxe dados reveladores da precariedade da infraestrutura das 
escolas no meio rural: $40 \%$ das escolas não possuem energia elétrica, $75 \%$ não possuem qualquer meio de comunicação de massa e menos de $1 \%$ tem acesso à internet, aproximadamente $50 \%$ das escolas possuem apenas uma sala de aula sendo $70 \%$ multisseriadas, $22 \%$ não possuem banheiro, $12 \%$ possuem horta ou outro tipo de espaço para práticas agropecuárias, menos de $8 \%$ possuem refeitório e menos de $6 \%$ quadra de esportes, menos de $1 \%$ laboratório de ciências e $2 \%$ possuem laboratório de informática, mais de $70 \%$ não possuem aparelho de som ou de TV e geladeira. Há tempos a qualidade e as condições das escolas de assentamentos eram objeto de preocupação no MST, para quem, a maior relação com o Estado a partir do Movimento por uma Educação do Campo, (Síntese da discussão da Coordenação Nacional de 2005), é necessária, mas insuficiente para atingir a educação escolar almejada.

A ausência de novas elaborações específicas sobre escola no período é significativa do refluxo teórico e prático em que se encontrava o Movimento em relação à instituição escolar. O Dossiê MST Escola, do Caderno de Educação n. 13, publicado em 2005, é a expressão dessa busca de retorno à escola. Trata-se de um caderno que aglutina os principais textos produzidos pelo MST e Setor de Educação sobre a escola no período de 1990 a 2001. $\mathrm{Na}$ apresentação do Caderno reconhece-se que nos últimos anos o Setor de Educação esteve voltado para outros campos e avalia-se que é o momento de voltar a discutir com a base o que se quer com as escolas dos assentamentos e quais as tarefas da escola na formação dos Sem Terra. Vejamos como isso se colocará no período mais recente.

\section{QUINTO PERÍODO: RETOMADA DAS ELABORAÇÕES SOBRE ESCOLA: RADICALIZAÇÃO NA CONCEPÇÃO, RECUO NAS LUTAS}

Quadro 5 - Quinto Período: Retomada das elaborações sobre escola: radicalização na concepção, recuo nas lutas.

\begin{tabular}{|c|c|c|c|}
\hline \multicolumn{4}{|c|}{ Concepções: Pedagogia Socialista e Educação Pública } \\
\hline MST - Contexto & Ano & Acontecimentos & Publicações/Documentos \\
\hline \multirow[t]{3}{*}{$\begin{array}{l}\text { Governos Lula e } \\
\text { Dilma, o MST é } \\
\text { base de apoio a } \\
\text { estes governos. }\end{array}$} & 2007 & $\begin{array}{l}\text { Seminário de Educação } \\
\text { Profissional da Região Sul. } \\
\text { Oficina de Elaboração } \\
\text { Pedagógica: Trabalho e } \\
\text { Educação. } \\
\text { I Seminário "O lugar da } \\
\text { Infância no MST". } \\
\text { Criação das Licenciaturas } \\
\text { em Educação do Campo. }\end{array}$ & $\begin{array}{l}\text { Programa de Reforma Agrária } \\
\text { (MST, 2007). } \\
\text { Relatório do Seminário sobre } \\
\text { Educação Profissional (ITERRA, } \\
\text { 2007). } \\
\text { Oficina de Elaboração } \\
\text { Pedagógica: Sistematização } \\
\text { (MST, 2007a). }\end{array}$ \\
\hline & 2008 & $\begin{array}{l}\text { Seminário O MST e a } \\
\text { Escola }\end{array}$ & $\begin{array}{l}\text { Relatório do Seminário “O MST } \\
\text { e a Escola” (MST, 2008). }\end{array}$ \\
\hline & 2009 & & \\
\hline
\end{tabular}


Quadro 5 - Quinto Período: Retomada das elaborações sobre escola: radicalização na concepção, recuo nas lutas.

(conclusão)

\begin{tabular}{|c|c|c|c|}
\hline \multirow[t]{4}{*}{$\begin{array}{l}\text { Refluxo na luta } \\
\text { por Reforma } \\
\text { Agrária. } \\
\text { Paralisação das } \\
\text { políticas de } \\
\text { assentamentos. }\end{array}$} & 2010 & & $\begin{array}{l}\text { CALDART. R. (org). Caminhos } \\
\text { para transformação da escola 1: } \\
\text { reflexões desde práticas da } \\
\text { licenciatura em Educação do } \\
\text { campo (Expressão Popular, } \\
\text { 2010). }\end{array}$ \\
\hline & 2011 & $\begin{array}{l}\text { Início do Curso de } \\
\text { Especialização "Marxismo } \\
\text { e Educação" com a } \\
\text { EPSJV/RJ }\end{array}$ & $\begin{array}{l}\text { Caderno da Infância n. 1: } \\
\text { Educação da Infância Sem Terra: } \\
\text { orientações para o trabalho de } \\
\text { base (MST, 2011). }\end{array}$ \\
\hline & 2012 & & \\
\hline & 2013 & & $\begin{array}{l}\text { Plano de Estudos das Escolas } \\
\text { Itinerantes MST/PR (MST, } \\
\text { 2013). }\end{array}$ \\
\hline $\begin{array}{l}\text { Enfrentamento } \\
\text { com o } \\
\text { agronegócio e o } \\
\text { capital } \\
\text { internacional. }\end{array}$ & 2014 & $\begin{array}{l}\text { Seminário Nacional sobre } \\
\text { os Complexos de Estudo. } \\
\text { II Seminário "O lugar da } \\
\text { Infância no MST". }\end{array}$ & $\begin{array}{l}\text { Boletim da Educação n. 12, } \\
\text { Edição Especial II ENERA } \\
\text { (MST, 2014a). }\end{array}$ \\
\hline \multirow[t]{2}{*}{$\begin{array}{l}\text { Lemas: "Por } \\
\text { Justiça Social e } \\
\text { Soberania } \\
\text { Popular!" e } \\
\text { "Lutar, Construir } \\
\text { Reforma Agrária } \\
\text { Popular!" }\end{array}$} & 2015 & II ENERA & $\begin{array}{l}\text { CALDART, R. STÉDILE, M. e } \\
\text { DAROS, D. (Org.). Caminhos } \\
\text { para transformação da escola 2: } \\
\text { agricultura camponesa, educação } \\
\text { politécnica e escolas do campo } \\
\text { (Expressão Popular, 2015). } \\
\text { SAPELLI, M., FREITAS, L. C. E } \\
\text { CALDART, R. (Org.). Caminhos } \\
\text { para transformação da escola 3: } \\
\text { organização do trabalho } \\
\text { pedagógico nas escolas do campo } \\
\text { (Expressão Popular, 2015). } \\
\text { Boletim da Educação n. 13: } \\
\text { Alimentação Saudável: um } \\
\text { desafio de todos (MST, 2015). }\end{array}$ \\
\hline & 2016 & $\begin{array}{l}\text { Jornada Cultural sobre } \\
\text { Alimentação Saudável }\end{array}$ & \\
\hline
\end{tabular}

Fonte: Elaboração da autora.

Como afirmamos na introdução, para recompor a história da escola no MST o presente artigo tomou por base a pesquisa realizada em tese de doutoramento, na qual, concluída em 2010, havíamos delimitado para análise o período entre 1979 e 2008. Trata-se neste momento de atualizar a análise, transcorridos oito anos. Em 2010 havíamos chegado aos quatro 


\section{Revista HIIST'TEIDBR On-line}

Artigo

doi: 10.20396/rho.v17i2.8645847

períodos apresentados acima, e indicávamos a abertura de um quinto momento, iniciado em 2007 e adentrado 2008, que denominamos à época "Tentativa de Retorno à Escola de Assentamento". Diante daquele contexto nos questionávamos se não deveríamos chamar de "retorno à escola do MST", uma vez que as escolas de acampamentos - Escolas Itinerantes não se incluíam na denominação que acabou prevalecendo. A escolha por "escola de assentamento", mais do que a área em que se encontrava, indicava uma determinada concepção de escola para a qual o termo assentamento parecia melhor corresponder, ao trazer presente a dimensão do trabalho e produção dessas áreas, a inserção das escolas desses territórios na regularidade do sistema público de educação, e por fim, a tentativa mesma de retomar a produção coletiva sobre escola, a qual teve como ponto mais fértil de sua história o período denominado "escola do trabalho ou escola de assentamento". A denominação do período atual e a concepção presente de escola indicam que a análise das tendências do momento que se iniciava em 2007 e 2008 foi captada corretamente.

Ainda na análise de 2010, indicávamos que no decorrer do segundo mandato de Lula as políticas em andamento já haviam dissolvido qualquer esperança da parte do MST de que este governo poderia promover mudanças sociais mais profundas. Ciente do quadro político nacional adverso ao avanço das lutas históricos dos trabalhadores, como a da Reforma Agrária, o Movimento, não sem contradições, atuava em dois campos fundamentais buscando: i) internamente: fortalecer a organicidade dos assentamentos, "massificar" os acampamentos, realizar formação política e técnica da base e multiplicar de militantes; ii) no âmbito externo pretendia: ampliar a relação com os setores urbanos, tanto promovendo a politização e a inter-relação com as organizações já existentes da classe trabalhadora, como impulsionando a criação de novos movimentos que abarcassem os setores desorganizados da sociedade. Nesse particular, em vista das dificuldades de mobilização dos trabalhadores rurais, o Movimento ensaiava também a organização de acampamentos com público das periferias urbanas.

Um olhar retrospectivo desses últimos oito anos nos permite afirmar que as contradições políticas se agudizaram e, para os setores de esquerda, adquiriram um tom dramático. Em âmbito internacional, o capitalismo viveu uma forte crise nos últimos dez anos, da qual esboça sair à sua maneira clássica, com arrocho sobre os trabalhadores, aprofundamento da dependência dos países subdesenvolvidos e expansão para novos mercados, regiões e áreas da economia, onde se destaca a educação que cada vez mais se transforma em mercadoria. (LEHER, 2014). Nessa fase do capital-imperialismo ganha relevância a desregulamentação do trabalho, as megafusões e o que Harvey (2014) chamou de acumulação por espoliação, da qual o Brasil é um alvo importante. No quadro de crise de acumulação do capital internacional, contudo, abriu-se brechas para o crescimento de países periféricos, como os agrupados nos $\mathrm{BRICS}^{6}$, para onde parte do capital migrou. No caso brasileiro, durante os primeiros governos petistas fomentou-se o que alguns analistas chamam de neodesenvolvimentismo (ALVES, 2014), o qual produziu um desenvolvimento econômico dentro da ordem burguesa que possibilitou o crescimento do capital financeiro de um lado e, de outro, dos setores econômicos ligados à economia primária, que reforçou a condição agroextrativista e dependente do país. No contexto de expansão econômica, sob um governo de origem popular, esses setores, ou ao menos parte deles, também obtiveram melhorias, como aumento real de salários e acesso ao emprego, políticas de crédito, ampliação da escolarização, integração racial, de gênero e diversidade, etc. Também foi 


\section{Revista HIIST'TEIDBR On-line}

promovida uma política de "conciliação de classes" na qual o capital ganhou muito e o povo, "muito pouco", mas este pouco serviu para deixar boa parte dos setores populares satisfeitos, considerando as condições anteriores ou históricas do país.

O ciclo de crescimento econômico brasileiro parece ter se esgotado e, com ele, a política de conciliação de classes. Este texto está sendo escrito em abril de 2016, em plena votação do impeachment da presidente Dilma Rouseff. O momento atual traz, para além das aparências, o embate de classes as quais, cessada a fase de crescimento econômico, não podem mais se conciliar. Mesmo os pequenos e contraditórios avanços obtidos pelos setores populares e progressistas são agora postos em questão, trazendo à tona as marcas do conservadorismo, do patrimonialismo e os resquícios escravagista, colonialista, e dependente, expressão do antagonismo social profundo.

No que se refere à atuação do MST no período em tela, esta desenrola-se em circunstâncias cada vez mais complexas e contraditórias. Pensamos que o sentido de existência do Movimento chegou a ser posto em questão mediante a conjugação de fatores como o avanço do agronegócio e a desmobilização em favor da necessidade de realização da Reforma Agrária, o refluxo das lutas de esquerda e da base social para as ocupações, o apoio do MST aos governos petistas que enfraquecia seu papel mobilizador e formador e o atrelamento às políticas federais que colocavam boa parte dos militantes na condição de gestores dessas políticas.

A fragmentação, a desmobilização e a cooptação de parte significativa da esquerda durante o período de "conciliação de classes" modularam a atuação do MST no período. No decurso dos governos do PT, a política de assentamentos rurais vem tendo resultados vergonhosos. Nunca se criaram tão poucos assentamentos, o que afetou a principal forma de pressão do MST, a mobilização social para as ocupações, fator também agravado pelas maiores oportunidades de trabalho no período. $\mathrm{O}$ avanço da perspectiva do capital no campo acabava por engolir grande parte da pequena agricultura e mesmo de muitos assentamentos, submetendo-os crescentemente à sua dinâmica, aprofundando os entraves para organização desses espaços como territórios livres. Se os pequenos agricultores e assentados melhoravam sua condição de vida, por meio das políticas federais como os programas habitacionais, Aquisição de Alimentos, Luz para Todos e programas de créditos, o era na maior parte dentro da própria lógica burguesa, sem necessariamente ampliar a consciência e a organicidade em vista de uma nova forma de vida no campo.

Programas como Assistência Técnica e PRONERA também continuaram. A assistência técnica cada vez mais limitada pela burocratização teve como um ganho qualitativo assumir uma orientação agroecológica, a qual também é assumida pelo MST desde 1999, ainda que com pequena relevância na base. O PRONERA, por sua vez, também sofria limitações como a falta de recursos, judicialização ${ }^{7}$ e tentativas de diminuir a participação dos Movimentos Sociais. O Programa foi gradativamente deixando de voltar-se à Educação de Jovens e Adultos e dirigindo-se à graduação e pós, possibilitando que boa parte dos filhos de assentados chegasse a cursos superiores em diversas áreas e mesmo à pósgraduação. Assinale-se, porém, que parte significativa da formação de militantes passa a ocorrer dentro de cursos formais e universidades, portanto menos moldada pelas lutas de base e pelo método formativo do MST. A formação de professores também foi deixando de estar sob a coordenação do Movimento e passa a ocorrer sobretudo em cursos de Licenciatura em 
Educação do Campo, os quais, viabilizados pelos MEC nas Universidades, já somam cerca de 40 cursos pelo país e dezenas de turmas já formadas, abrangendo um largo leque de público, mas sob variadas perspectivas teóricas e pedagógicas. (SANTOS, 2011). Em contraposição, mais de 30 mil escolas no campo foram fechadas nos últimos anos (RELATORIO DA II PESQUISA NACIONAL SOBRE EDUCAÇÃO NA REFORMA AGRÁRIA, 2015), expressão do êxodo rural e das políticas de nucleação de escolas no campo.

Nesse cenário, a questão que se põe ao Movimento não é apenas quanto à sobrevivência como movimento social, mas quanto ao tipo de movimento social que pretende ser e fazer.

\begin{abstract}
Em toda sua história, o MST movimentou-se entre a radicalidade de suas práticas de ocupação e a luta institucional para viabilizar os assentamentos e acomodar as famílias trabalhadoras em seus lotes. A contradição da reforma agrária de mercado bateu às portas do movimento, exigindo a incômoda definição entre atender às contingências do mercado, com camponeses-empreendedores integrados ao capitalismo agrário, fomentar uma indigesta luta de classes em seu interior ou perseverar na formação de trabalhadores conscientes de seu papel histórico na construção do socialismo. Eis a sua [do MST] mais profunda tensão interna: pôr em memória as conquistas do passado, defender sua "vocação camponesa", apostar no empreendedorismo de alguns assentamentos, refluir nas lutas e institucionalizar-se; ou denunciar os limites cada vez mais estreitos que o capital, através de instrumentos privados e estatais, impõe a sua existência como alternativa societária - quase sempre problemática - no interior da ordem. Mais, enfrentar, com a positividade que a luta de classes exige, a proletarização de sua base social, convertida num enorme celeiro de força de trabalho disponível para o capital no campo e na cidade. Os caminhos da "revolução na ordem" se esgotaram. As condições atuais da realidade objetiva se definem por um padrão de acumulação essencialmente destrutivo, o que impõe severa crítica a toda e qualquer via de desenvolvimento - incluindo aí o neodesenvolvimentismo - que se venha formular para a reprodução do sistema sócio-metabólico do capital. Isso obviamente envolve o sentido histórico e a função social da Reforma Agrária a serem dados pela base social do MST, cuja história revela com nitidez cada vez maior a contradição de se pretender seguir os dois caminhos concomitantemente. (PINASSI, 2014, grifo do autor).
\end{abstract}

De sua parte, o Movimento indica que sua relação com o Estado e governos se dá na base da pressão popular e que é preciso combinar mobilização e negociação. Em relação aos governos petistas, afirma que sua base social foi beneficiada de alguma maneira e é simpática ao projeto neodesenvolvimentista, mas considera sua postura em relação a esses governos como de "autonomia crítica". Essa estratégia de ação nas duas frentes de pressão e negociação, que também é de formação da consciência nas lutas concretas moduladas pelas relações com o Estado e as políticas públicas, também é visível nas ações educacionais.

Vejamos, por exemplo, as ideias principais presentes nos documentos do início do período atual (MOVIMENTO SEM TERRA, 2006, 2007, 2007a): Lutar e pressionar o Estado para criação e melhoria das escolas existentes nos assentamentos e para ampliar o nível de ensino ofertado; Acesso e criação de escolas de educação profissional voltadas às necessidades produtivas das áreas de reforma agrária; A luta por escola deve ser realizada pelas próprias famílias que precisam ser sujeitos da luta pelo direito à educação, a escola nas 


\section{Revista HIIST'TEIDBR On-line}

próprias áreas favorece a permanência das famílias no campo; $\mathrm{O}$ acesso à escola encontrase no campo dos direitos e somente é universalizado pelo poder público, ou seja, o MST precisa estabelecer relações com o Estado em vista da universalização do direito à educação, ainda que seja na forma de pressão e luta; A escola deve estar em sintonia com a luta do MST, relacionando-se especialmente com os campos da produção, cultura, comunicação, valores, organicidade; Formação de professores própria para a realidade do campo; Centralidade dos sujeitos, sua cultura e seus tempos de vida; O estudo como dimensão fundamental para o avanço da luta por reforma agrária; Todo Sem Terra deve estar estudando, das crianças aos idosos, da base aos dirigentes, seja na EJA, na escola formal, nas cirandas infantis, em cursos informais, na universidade, todos devem buscar se qualificar; A educação é maior e acontece para além da escola, o sentido da educação deve ser a construção de uma nova sociedade; A escola é um espaço importante que deve ser ocupado, somando esforços na perspectiva maior do Movimento.

A luta pelo ensino médio e a educação profissional é reforçada devido ao elevado número de jovens presentes nos acampamentos e assentamentos e o insignificante número de unidades escolares com ensino médio nessas áreas. Calcula-se que em 2010 somavam pouco mais de 50 unidades ofertando o nível médio num contexto de 2500 que ofereciam o ensino fundamental, ao passo que, de 203 mil jovens entre 15 e 17 anos vivendo em assentamentos, cerca de 47 mil estavam fora da escola e apenas 28 mil cursavam o ensino médio. (MOVIMENTO SEM TERRA, 2006). Os jovens representam para o MST um público estratégico, o setor de educação atuando nesta direção, tem pensado o ensino médio e a educação profissional visando basicamente duas perspectivas: formação para os jovens (em várias dimensões, e com destaque para a inserção no mundo do trabalho) e impulso para o projeto de assentamento do MST. (MOVIMENTO SEM TERRA, 2006).

Dessa forma, os temas da juventude, Ensino Médio e formação profissional são bem presentes. Mas é importante destacar também o debate acerca da Infância no MST, trazendo a formação humana em perspectiva histórica, sobretudo nas fases iniciais da vida. A infância Sem Terra ganhou dois seminários (em 2007 e 2009) e publicações próprias, como a Revista Sem Terrinha e o Jornal Sem Terrinha, ambos com tiragem regular. Nesse contexto, também se colocou o debate sobre a escola, cujo sentido educativo e proposta são recolocados desde a Oficina de Elaboração Pedagógica realizada em 2007 (MOVIMENTO SEM TERRA, 2007a) e em 2008 no Seminário "O MST e a Escola".

Um elemento novo no debate sobre escola e que contribui para delimitação do período ora em foco refere-se ao experimento com a Pedagogia Socialista Russa, sobretudo nas Escolas Itinerantes no estado do Paraná, iniciado em 2010 (MOVIMENTO SEM TERRA, 2014b) e que já se espalha por várias outras escolas e Estados. As formulações russas tornaram-se atualmente a principal fonte nos debates e elaborações do MST desde então. Nossos estudos anteriores (DALMAGRO, 2010) e mesmo algumas produções do MST (MOVIMENTO SEM TERRA, 2014a) indicavam que havia impasses e limitações quanto às formulações escolares no Movimento, o que acabou gerando nos anos 2000 certa paralisia nas produções sobre escola e um vácuo no diálogo com as escolas em suas áreas. Essas limitações se faziam sentir sobretudo nos anos finais da educação fundamental e ensino médio, e possuíam relação coma referência freiriana que até então mais se destacava. É nesse contexto, que, a propósito da elaboração de subsídios para as Escolas Itinerantes no estado do Paraná, tem início o experimento mencionado acima, embasado na experiência 


\section{Revista HIIST'TEIDBR On-line}

russa desenvolvida entre 1917 e 1931. (FREITAS, 2009). É da Pedagogia Socialista russa que advém hoje a retomada da elaboração sobre a concepção de escola no MST, evidente no crescimento das publicações nesse período em comparação com os dois anteriores. Destaque-se também a realização de um seminário nacional sobre os complexos de estudo em 2014, além da publicação pela Editora Expressão Popular de livros inéditos no Brasil dos autores russos Pistrak (2009, 2015) e Shulgin (2013), traduzidos pelo professor Luis Carlos de Freitas, da Unicamp, hoje um dos principais interlocutores do Setor de Educação do MST. Diante dessa realidade podemos adjetivar a concepção de escola do período atual como Escola do Trabalho ou Pedagogia Socialista, o que curiosamente ocorre num contexto em que muitos atribuem ao Movimento um rebaixamento de suas bandeiras históricas.

Em nossa análise, a aproximação com a pedagogia russa tem possibilitado uma visão mais profunda e articulada de escola, assim como maior ciência da complexidade para sua transformação. Este avanço qualitativo na concepção de escola se deve ao fortalecimento da teoria materialista histórico-dialética e da Pedagogia Socialista no interior do Setor de Educação do MST e ao estudo e esforços sistemáticos para realização do experimento nas Escolas Itinerantes no Paraná. Desses esforços tem resultado, a nosso ver, uma visão mais orgânica do trabalho escolar, o qual se expressa na melhor compreensão e articulação entre conhecimento, trabalho, lutas sociais e auto-organização dos estudantes no interior da escola. Noções anteriores a exemplo de "prática como base da aprendizagem", "realidade como base do conhecimento", "tempos educativos", "formação integral", entre outras, tem ganho saltos qualitativos.

O referencial marxista na educação do MST e uma revisão crítica de sua produção também ganha impulso a partir de novas articulações dentro do Setor de Educação do MST. Nesta direção, podemos citar o Curso de Especialização com a Escola Politécnica de Saúde Joaquim Venâncio (EPSJV), cujo nome oficial é "Trabalho, Educação e Movimentos Sociais", popularmente denominado "Marxismo e Educação". Este curso, já com duas turmas concluídas, reflete a busca pelo referencial teórico mencionado, num contexto em que a formação proporcionada pelas universidades cada vez mais se pautava pelas perspectivas pós-modernas.

O tema da Pedagogia Socialista e da fundamentação marxista também se fez presente no II ENERA, realizado em 2015, maior encontro educacional do MST. Mas o II ENERA também deixou evidente o debate acerca da educação pública e da luta contra as forças para sua privatização e mercantilização. O sistema público educacional é um tema para o MST neste último período, ainda que desde seus primórdios as escolas de assentamento e acampamento estejam ligadas às redes estaduais e municipais de ensino e, portanto, sofrendo a interferência do Estado com o qual o MST disputa a orientação para as escolas. Na atualidade, porém, esta questão se põe como um tema, decorrente do crescente interesse do capital pelo sistema educacional e, por outro lado, da inserção do Movimento nas disputas por políticas públicas e ainda da aproximação a grupos marxistas com tradição de análise acerca do Estado e das políticas educacionais. Ressalte-se ainda que a dificuldade de implementar sua proposta de educação de forma massiva nas escolas deve-se, em grande parte, aos limites burgueses da instituição escolar e do sistema educacional, ao qual o Movimento busca contrapor-se com as formulações da Pedagogia Socialista, portadora de outro formato escolar e demandas para as políticas educacionais. Este parece ser o ponto mais atual do debate educacional no MST: afirmar uma proposta de escola pública, de 
conteúdo classista e de perspectiva socialista, portadora de um conteúdo e forma que não podem ser absorvidos pelo sistema e escola burgueses e que ao mesmo tempo não corresponde à organização de suas áreas e às lutas do MST nesse período.

Por último, é importante destacar que no período atual a perspectiva agroecológica tem marcado presença também da área educacional. Se na Escola do Trabalho do início dos anos 1990 a tônica era a cooperação dos assentamentos, agora, ainda em sintonia com o setor de produção, a agroecologia é apontada como uma alternativa à produção no campo. Essa questão tem ressonância no conjunto do MST, o qual tem combatido a perspectiva do capital no campo, expressa no uso de venenos, monocultivo, e altas taxas de investimento. A agroecologia transparece como um ponto comum entre as escolas ligadas ao MST, possuindo potencial para articular os conhecimentos da área das ciências sociais e naturais, o que está em consonância com os experimentos atualmente em curso, consistindo ainda em orientação para diversos cursos profissionalizantes. Isto se traduz em um Boletim de Educação Especial (MOVIMENTO SEM TERRA, 2015) e na realização de uma Jornada sobre Alimentação Saudável em 2016, tema que ganha a sociedade e a formação escolar no Movimento.

Em síntese, o momento atual evidencia, como seu nome sugere, uma retomada na produção coletiva do MST acerca da escola, com aprofundamento e radicalização em suas formulações. Este debate chega a muitas das escolas em suas áreas, animando o trabalho que desenvolvem, porém, é grande o esforço a ser feito nas áreas de acampamento e assentamentos dado o elevado número de escolas e de campos de atuação e mesmo os desafios para organização destes. A crise por que passa a esquerda brasileira e as dificuldades de organização popular, ambas afetas ao MST, precisam ser encaradas frontalmente para que a radicalização na proposta educacional encontre materialidade.

\section{CONSIDERAÇÕES FINAIS}

O texto se propôs a refletir acerca do significado da experiência com educação escolar no interior do MST, por meio da análise do percurso da escola neste Movimento Social. Esta reconstrução histórica possibilitou identificar algumas questões importantes que apresentamos sinteticamente a título de conclusão.

O MST ao longo de toda sua trajetória ocupou-se da temática escolar e mais amplamente, da formação humana. Observamos uma íntima articulação entre as lutas mais gerais do Movimento em cada período e as produções sobre escola. Podemos afirmar a existência de sintonia entre projeto social e projeto educacional, sintonia que reflete as lutas encampadas pelo MST nos diferentes momentos de sua história. Os assentamentos moldam a concepção de escola pelos desafios do trabalho e da produção da vida no campo, os acampamentos produziram a Escola Itinerante e inspiram, por sua forma de organização, a organização das escolas.

A trajetória do MST com escola revela uma expansão do trabalho com educação que vai da escola primária, nos anos 1980 e início de 1990, chegando ao Ensino Médio nos anos 2000 e mesmo à graduação e pós-graduação nos períodos mais recentes. Esta expansão também abrange a EJA, a Educação Profissional, a Educação Infantil, e culmina na luta por políticas públicas como o PRONERA e no Movimento por uma Educação do Campo. Entretanto, contrariamente à expansão do MST e de e à abrangência de sua atuação, 
movimento também acompanhado na educação, é perceptível a diminuição da influência deste no conjunto das escolas, o que refletia as dificuldades organizativas nos assentamentos e o atrelamento de muitas escolas ao Estado.

As análises indicam ainda para a importância da educação e da escola dentro deste Movimento Social. Ainda que a escola não seja a principal aposta do MST no processo de formação de consciência, é evidente o crescimento da escolarização na formação de militantes e o papel atribuído à escola nas lutas por transformação social. A pesquisa histórica evidencia que nos momentos em que a luta mais ampla tem dificuldade de avançar, há tendência de que o papel atribuído à educação formal ganhe destaque. O trabalho de base, seja nas escolas, nos assentamentos ou acampamentos, é assinalado como algo que deve ser retomado há mais de quinze anos, porém esta orientação encontra dificuldade para se concretizar. O período atual denominado "Retomada das elaborações sobre escola: radicalização na concepção, recuo nas lutas”, expressa a contradição entre a radicalização na concepção e afirmação da Pedagogia Socialista num tempo em a luta geral do Movimento encontra-se mais confinada nos limites do direito burguês.

Quanto às bases pedagógicas para a construção da proposta educacional do Movimentos e evidencia a presença da Educação Popular de Paulo Freire e da Pedagogia Socialista, em particular, a Russa. Ambas se encontram na base das produções e experiência do MST entre 1979 até a metade dos anos 1990. Neste sentido podemos assinalar a base da proposta do MST em concepções educacionais críticas e com marca classista, sobretudo até 1996. Entre 1996 e 2006 temos as formulações "Pedagogia do MST" e "Educação do Campo", marcadas por maior ecletismo teórico e menor fertilidade na concepção de escola, refletindo na diminuição da produção coletiva. A Educação do Campo marca o trânsito de uma concepção anterior pautada no trabalho e nas lutas de classe para uma concepção centrada na cultura e na identidade Sem Terra e camponesa. (VENDRAMINI, 2009; OLIVEIRA; DALMAGRO, 2014). Este também é o período em que mais militantes estudavam e se ampliou o leque de atuação educacional, enquanto contraditoriamente, há menor incidência nas escolas. O período que se desenrola a partir de 2008, retoma na área educacional, a perspectiva de classe com a afirmação da Pedagogia Socialista como principal fonte para as novas elaborações teóricas. A radicalização na teoria, porém, não encontra consonância nas lutas gerais desenvolvidas pelo MST no período, devido ao apoio, ainda que parcial, às políticas neodesenvolvimentistas as quais implicaram na desmobilização de sua base social para lutas de superação da ordem.

No que se refere ao trabalho que efetivamente se desenvolve nas escolas de assentamentos e acampamentos, pensamos não ser exagero afirmar que estes abrigam uma das mais relevantes experiências de escolas na perspectiva dos trabalhadores na atualidade. Mas nestas áreas também se encontram os problemas mais dramáticos da realidade educacional brasileira como as difíceis condições de infraestrutura e de formação de educadores ou a ausência de escolas. Mudar a realidade educacional no campo brasileiro, assim como a questão fundiária, é um desafio não apenas para o MST mas para toda a sociedade brasileira.

Em que pesem as oscilações e contradições presentes nas formulações educacionais do MST, é evidente uma concepção de escola orgânica à sua luta e com importantes contribuições para uma perspectiva educacional classista. Uma experiência de educação 
formal de proporção incomum entre os movimentos de trabalhadores que ficará marcada na história da educação no Brasil.

\section{REFERÊNCIAS}

ALVES, G. O mal-estar do neodesenvolvimentismo. Blog da Boitempo Editorial. 2014. Disponível em: <https://blogdaboitempo.com.br/2014/11/27/o-mal-estar-do-neodesenvol vimentismo/>. Acesso em: 21 abr. 2016.

CALDART, R. S. Caminhos para transformação da escola 1: reflexões desde práticas da licenciatura em Educação do campo. São Paulo: Expressão Popular, 2010.

CALDART, R. S. Pedagogia do Movimento Sem Terra. 3. ed. São Paulo: Expressão Popular, 2004.

CALDART, R. S.; SCHWAAB, B. Nossa luta é nossa escola: a educação das crianças nos acampamentos e assentamentos. In: Caderno de Educação, n. 13, Edição Especial. São Paulo, 2005. (Publicado originalmente em Fundep/DER e MST/RS, 1990).

CALDART, R. S.; STÉDILE, M. H.; DAROS, D. Caminhos para transformação da escola 2: agricultura camponesa, educação politécnica e escolas do campo. São Paulo: Expressão Popular, 2015.

CAMINI, I. Escola itinerante: na fronteira de uma nova escola. São Paulo: Expressão Popular, 2009.

CONDE. S. F. Linha do tempo. In: AUED. B. W.; PAULILO, M. I. S. (Org.). Agricultura familiar. Florianópolis: Insular, 2004.

DALMAGRO, S. L. A escola no contexto das lutas do MST. 2010. 314 f. Tese (Doutorado em Educação) - Universidade Federal de Santa Catarina, Florianópolis, 2010.

DALMAGRO, S. L. Consolidação da proposta de escola no MST. 1 quadro. Elaboração da autora.

DALMAGRO, S. L. Construção da questão escolar no MST. 1 quadro. Elaboração da autora.

DALMAGRO, S. L. Da escola à educação no MST. 1 quadro. Elaboração da autora.

DALMAGRO, S. L. Manifestação e "crise" da escola. 1 quadro. Elaboração da autora.

DALMAGRO, S. L. Retomadas das elaborações sobre escola: radicalização na concepção, recuo nas lutas. 1 quadro. Elaboração da autora.

FIGUEIRA, P. A. A educação de um ponto de vista histórico. INTERMEIO, Revista do Mestrado em Educação, Campo Grande, v. 1, n. 1, 1985. 
FREITAS, L. C. A luta por uma pedagogia do meio: revisitando o conceito. In: PISTRAK, Moisey M. (Org.). A Escola-Comuna. São Paulo: Expressão Popular, 2009.

GLÉNISSON, J. Iniciação aos estudos históricos. 5. ed. Rio de Janeiro: Bertrand Brasil, 1986.

HARVEY, D. O novo imperialismo. 8. ed. São Paulo: Loyola, 2014.

ITERRA. Documento do Seminário sobre Educação Profissional para as áreas de Reforma Agrária da Região Sul.Cadernos do Iterra, Veranópolis, ano 7, n. 13, 2007.

LEHER, R. Organização, estratégia política e o Plano Nacional de Educação. In: Encontro nacional de educadoras e educadores da reforma agraria, II ENERA. Textos para Estudos e Debate. São Paulo. Boletim de Educação, n. 12, edição especial. São Paulo: MST, 2014. p. 71-90.

LUKÁCS, G. Introdução a uma estética marxista. 2. ed. Rio de Janeiro: Civilização Brasileira, 1968.

MÉSZÁROS, I. A teoria da alienação em Marx. São Paulo: Boitempo, 2006.

MOVIMENTO SEM TERRA. MST. A educação no MST: desafios e diretrizes para superá-los. Síntese da discussão da Coordenação Nacional. Goiânia, junho de 2005. (Não publicado).

MOVIMENTO SEM TERRA. MST. A importância da prática na aprendizagem das crianças. In: Dossiê MST Escola: Documentos de Estudo 1990 - 2001. Caderno de Educação n. 13. Edição especial. São Paulo, 2005a. p. 83-87. (Publicado originalmente em 1993).

MOVIMENTO SEM TERRA. MST. Alimentação Saudável: um desafio de todos. Boletim da Educação n. 13. São Paulo, 2015.

MOVIMENTO SEM TERRA. MST. Caminhos da Educação Básica de Nível Médio para a Juventude das áreas de Reforma Agrária. Documento Final do $1^{\circ}$ Seminário nacional sobre educação básica de nível médio nas áreas de reforma agrária. Luziânia, setembro de 2006. (Não publicado).

MOVIMENTO SEM TERRA. MST. Como deve ser a escola de um assentamento. Boletim da Educação n. 1. São Paulo, 1992a.

MOVIMENTO SEM TERRA. MST. Como fazemos a escola de Educação Fundamental. Caderno de Educação n. 9. São Paulo, 1999.

MOVIMENTO SEM TERRA. MST. Como fazer a escola que queremos. Caderno de Educação n. 1. In: Dossiê MST Escola: Documentos de Estudo 1990 - 2001. Caderno de Educação n. 13. Edição Especial. São Paulo, 2005a. p. 105-136. (Publicado originalmente em 1992b). 
MOVIMENTO SEM TERRA. MST. Dossiê MST Escola: Documentos de Estudos 1990 2001. Caderno de Educação n. 13. Edição Especial. São Paulo, 2005a.

MOVIMENTO SEM TERRA. MST. Educação da Infância Sem Terra: orientações para o trabalho de base. Caderno da Infância n. 1. São Paulo, 2011.

MOVIMENTO SEM TERRA. MST. Educação. In: Documento básico do MST. Piracicaba: MST, 1991.

MOVIMENTO SEM TERRA. MST. Educação no MST: Balanço 20 anos. Boletim da Educação n. 9. São Paulo, 2004.

MOVIMENTO SEM TERRA. MST. Encontro nacional de educadoras e educadores da reforma agraria, II ENERA. Textos para Estudos e Debate. São Paulo. Boletim de Educação n. 12, Edição Especial. São Paulo, 2014a.

MOVIMENTO SEM TERRA. MST. Ensino de $5^{\mathrm{a}}$ a $8^{\mathrm{a}}$ série em áreas de assentamento: ensaiando uma proposta. São Paulo: MST, 1995 b.

MOVIMENTO SEM TERRA. MST. Escola, Trabalho e Cooperação. Boletim da Educação n. 4. São Paulo, 1994.

MOVIMENTO SEM TERRA. MST. Lutas e Conquistas. Secretaria Nacional MST, 2. ed. São Paulo, 2010.

MOVIMENTO SEM TERRA. MST. MST/PARANÁ. Memória dos encontros dos Complexos de Estudo (2010 - 2014). 2014b. (arquivo digital). (Não publicado).

MOVIMENTO SEM TERRA. MST. O que queremos com as escolas de assentamentos. Caderno de Formação n. 18. São Paulo, 1991a.

MOVIMENTO SEM TERRA. MST. O trabalho e a coletividade na educação. Boletim da Educação n. 5. São Paulo, 1995a.

MOVIMENTO SEM TERRA. MST. Oficina de elaboração pedagógica: Sistematização. Veranópolis, 2007a. (Não publicado).

MOVIMENTO SEM TERRA. MST. Os desafios do Setor de Educação. In: Construindo o Caminho. São Paulo, 2001.

MOVIMENTO SEM TERRA. MST. Pedagogia do Movimento Sem Terra: Acompanhamento às Escolas. Boletim da Educação n. 8. São Paulo, 2001a.

MOVIMENTO SEM TERRA. MST. Princípios da Educação no MST. Caderno de Educação n. 8. São Paulo, 1996.

MOVIMENTO SEM TERRA. MST. Programa de Reforma Agrária. Brasília, 2007. 
OLIVEIRA, M.; DALMAGRO, S. L. A questão agrária, a Educação do Campo e os projetos em disputa. Reflexão e Ação, Santa Cruz do Sul, v. 22, n. 2, p. 94-119, jul./dez. 2014.

PINASSI, M. O. Balanço dos 30 anos do MST. Correio da Cidadania. São Paulo, 9 mar. 2014.

PISTRAK, M. A Escola-Comuna. São Paulo: Expressão Popular, 2009.

PISTRAK, M. Ensaios sobre a Escola Politécnica. São Paulo: Expressão Popular, 2015.

RELATORIO DA II PESQUISA NACIONAL SOBRE EDUCAÇÃO NA REFORMA AGRÁRIA, 2., 2015, Brasília. Anais..., Brasília: INCRA, PRONERA, UNESCO, UNESP, IPEA, MDA, 2015.

SANTOS, C. F. Relativismo e escolanovismo na formação do educador: uma análise Histórico-Crítica da Licenciatura em Educação do Campo. 2011. 268 f. Tese (Doutorado em Educação) - Universidade Federal da Bahia, Salvador, 2011.

SAPELLI, M. L. S.; FREITAS, L. C.; CALDART, R. S. (Org.). Caminhos para transformação da escola 3: organização do trabalho pedagógico nas escolas do campo. São Paulo: Expressão Popular, 2015.

SAPELLI, M. L. S.; FREITAS, L. C.; CALDART, R. S. Plano de estudos da escola itinerante. Cascavel: MST/Paraná, 2013.

SHULGIN, V. N. Rumo ao politecnismo. São Paulo: Expressão Popular, 2013.

VENDRAMINI, C. A educação do campo na perspectiva do materialismo histórico dialético. In: COUTINHO, A. F. (Org.). Diálogos sobre a questão da Reforma Agrária e as políticas de educação do campo. São Luís: Ed. da EDUFMA, 2009.

\section{Notas}

\footnotetext{
${ }^{1}$ Professora do Centro de Ciências da Educação da Universidade Federal de Santa Catarina. Desenvolve estudos na interface entre Escola, Trabalho, Movimentos Sociais e Educação do Campo. sandradalmagro@yahoo.com.br

${ }^{2}$ Instituto Técnico de Capacitação e Pesquisa da Reforma Agrária, localizado em Veranópolis/RS.

${ }^{3}$ Depoimentos obtidos durante a pesquisa.

${ }^{4}$ Em 2005 a Escola Itinerante estava legalmente reconhecida em cinco Estados. O Rio Grande do Sul teve aprovação em 1996, o Paraná em 2003, em Santa Catarina em 2004, Goiás e Alagoas em 2005, Piauí em 2008. Neste ano de 2016 encontra-se em funcionamento apenas no estado do Paraná, tendo sido fechada de forma autoritária pelos governos estaduais ou em decorrência das dificuldades para realizar acampamentos massivos. Trata-se de uma construção original de escola, adequada às condições da luta pela terra, e menos amarrada ao Estado. Sobre a Escola Itinerante ver Camini (2009).

${ }^{5}$ Pesquisa Nacional da Educação na Reforma Agrária, realizada em 2004 pelo INEP, em 6338 assentamentos. Calcula-se que $25 \%$ das áreas pesquisadas tenham vínculo com o MST.
} 
${ }^{6}$ BRICS: Brasil, Rússia, China e África do Sul. A expressão se refere ao grupo econômico constituído extraoficialmente por estes países subdesenvolvidos, mas com presença importante na economia internacional. 7 A judicialização do PRONERA pode ser observada em um Acórdão do Tribunal de Contas da União, em 2008, que paralisou boa parte do Programa e restringiu a participação dos Movimentos Sociais na execução dos mesmos, modificando as regras para celebração de convênios nas Universidades com os parceiros do Programa. Também se expressou no questionamento judicial para a abertura de algumas turmas em Universidades. Dois casos exemplares são o Curso de Direito na Universidade Federal de Goiás e o Curso de Medicina Veterinária na Universidade Federal de Pelotas, mas também em outros casos, notadamente em áreas de formação historicamente reservadas às elites.

${ }^{8}$ Saviani situa a Pedagogia do MST como uma expressão da "Pedagogia do Campo" e aponta afinidades destas com as Pedagogias da Educação Popular e interlocução com a Pedagogia da Prática.

Submetido em: 30/04/2016

Aprovado em: 22/07/2017 